\title{
Anti-proliperative and Anti-metastatic Agents of Balinese Long Pepper (Piper retrofractum V) Extract in Breast Cancer
}

\author{
Made Violin Weda Yani, Varennia Bhargah, I Gede Agus Darsana Palgunadi, Ni Putu Sri Indrani \\ Remitha, I Made Winarsa Ruma \\ Faculty of Medicine, Udayana University, Denpasar, Indonesia \\ violinweda@student.unud.ac.id \\ DOI: http://doi.org/10.29080/jhsp.v4i1.258
}

Received: Oktober 2019, Accepted: Oktober 2019, Published: April 2020

\begin{tabular}{|c|c|}
\hline Keywords & Abstract \\
\hline $\begin{array}{l}\text { Anti-metastatic } \\
\text { Anti- } \\
\text { proliperative } \\
\text { Breast Cancer } \\
\text { Piperine } \\
\text { Piper } \\
\text { retrofractum }\end{array}$ & $\begin{array}{l}\text { Breast cancer is malignancy that becomes significant health problem in the } \\
\text { world According to WHO data in 2018, there were } 2.1 \text { million cases of breast } \\
\text { cancer with mortality rate reaching 627,000. Current breast cancer treatments } \\
\text { are surgery, radiation therapy, hormonal therapy and chemotherapy. However, } \\
\text { these treatments have side effects such as neuropathy, fatigue after undergoing } \\
\text { chemotherapy, and alopecia. Natural ingredients are the choice to overcome } \\
\text { these weaknesses, one of which is the utilization of piperine in Balinese long } \\
\text { pepper (Piper retrofractum Vahl). Piperine can increase the bioavailability of } \\
\text { many drugs by increasing absorption from the intestine, suppressing the } \\
\text { metabolism of drugs in lung and liver tissue by inhibiting CYP3A4 and P84 } \\
\text { glycoprotein P84. Piperine is easily absorbed in the intestine and excreted } \\
\text { through urine and feces, causing minimal toxic effects. Piperine in Balinese long } \\
\text { pepper is able to reduce breast cancer cell proliferation by } 40 \% \text {. Piperine can also } \\
\text { inhibit epidermal growth factor (EGF) by inducing decreased expression of MMP- } \\
9 \text { and MMP-13. Piperine will work through inhibition of NF-KB and PKC } \\
\text { phosphorylation and AP-1 activation by interfering extracellular signal-regulated } \\
\text { kinase (ERK) signaling pathway (ERK) 1/2, p38 MAPK, and Akt which results in } \\
\text { inhibition of migration and metastasis of breast cancer cells. }\end{array}$ \\
\hline
\end{tabular}

\section{Introduction}

Breast cancer is malignancy that is a major health problem in the world According to World Health Organization (WHO) statistics in 2018, there are 2.1 million diagnosed breast cancer events and 627,000 deaths with $90 \%$ of cases found at advanced stage or metastasis(1). Data from the International Agency for Research on Cancer (IARC) in 2018 shows that breast cancer is the most common diagnosed cancer in women, reaching $24.2 \%$ or about 1 in 4 new cases of cancer diagnosed in women worldwide (2). The incidence of breast cancer in Indonesia is recorded at 42.1 per 100,000 population in 2018 with average mortality rate of 17 per 100,000 population (3). Based on data from Bali Provincial Health Office in 2011, $75 \%$ of breast cancer patients were diagnosed at advanced stage and $25 \%$ at early stage (4).

Data from Association of Indonesian Surgical Oncologists, patients with stage 0 breast cancer have $98 \%$ life expectancy for 10 years, stage II have $60-70 \%$ within a period of 5 years, stage III have $30-50 \%$ life expectancy and stage IV have 15\% life expectancy (5). Treatments of breast cancer that are used today including surgery (mastectomy or lumpectomy), radiation therapy, hormonal therapy and chemotherapy, which can be adjusted to the stage and type of breast cancer (6). However, treatments of breast cancer have several weaknesses such as chemotherapy that cause many side effects like neuropathy, cardiomyopathy, leukemia, and excessive fatigue after undergoing chemotherapy, and alopecia that is felt by more than $50 \%$ of breast cancer patients.

Metastatic condition is characterized by the spread of cancer cells from primary tumors to other normal body tissues initiated by cell release from primary tumors, invasion and migration, intravasation, 
transport through blood vessels or lymph, extravasation and formation of secondary tumors. Generally, breast cancer will metastasize to the bones, skin, liver, lung and adrenal. Increased cancer cell metastasis to other parts of the body will cause higher morbidity and mortality rates (6).This condition causes the need for alternative therapies with minimum side effects for breast cancer.

Natural ingredients are often thought to be the choice to overcome current weaknesses of cancer treatment. One of the potential natural ingredients for anti-cancer therapy is Piper retrofractum Vahl. Piper retrofractum Vahl has many local names such as, cabai jawa (Java), cabi sola (Madura), cabia (Sulawesi), lada panjang (Malay) and tabia bun (Bali). Balinese long pepper is also called tabia bun is a part of Ayurveda which is a science that studies medicinal plants to improve human health following these phases, which are, cleansing, cell rejuvenation and disease management (7). In Indonesia, Balinese long pepper plant is designated as traditional medicinal plant by the Indonesian Food and Drug Supervisory Agency with superior compounds, namely piperine and flavonoid, as well as other ingredients such as cavisin, essential oils, and saponins. The pharmacological properties of Piper retrofractum Vahl including antioxidant, antimalarial, antibacterial, central nervous depressant activity, antidiabetic and even anticancer (7). The purpose of this article review is to determine the effectiveness of tabia bun (Piper Retrofractum V) as an anti-proliferation and anti-metastatic agent in breast cancer.

\section{Method}

Writing a scientific paper, this literature review using literature study method. The literature sources consist of relevant journals from search engines such as www.pubmed.com, proquest.com, and scholar.google.com. Using the keyword: Anti-metastatic, Anti-proliperative, Breast Cancer, Piperine, Piper retrofractum. The inclusion criteria are all breast cancer samples, and references should not exceed the last ten years unless there is no new study related to the contents of the reference. Forty-five journals have been reviewed, 21 of them were found suitable as a reference for this literature.

\section{Result}

\section{General Overview of Breast Cancer}

Breast cancer can occur due to interaction between environmental and genetic factors. The pathogenesis begins with invasive cancer cells that arise due to molecular mutations and cellular signaling pathways. The PI3K / AKT pathway and the RAS / MEK / ERK pathway is able to protect normal cells from cell death. When mutations occur in genes that encode these pathways, cells become unable to carry out apoptosis when they are no longer needed, thus leading to cancer development. Some mutations associated with breast cancer are p53, BRCA1 and BRCA2. Mutation conditions will cause uncontrolled cell proliferation, lack of attachment and metastasis to distant organs (8). According to The Cancer Genome Atlas Network (TCGA), there are four subtypes of breast cancer with genetic deviations namely Luminal A, Luminal B, Basal- Like, and HER-2 Positive (9).

Luminal A breast cancer is the most common subtype. This type has characteristics which are positive estrogen receptor (ER), and/or positive progesterone receptor (PR), and negative Human endothelial growth Factor Receptor 2 (HER2). This subtype is usually found at low stage breast cancer with low aggressiveness level, thus it has good prognosis. Meanwhile, luminal B breast cancer has characteristic like positive ryaotu estrogen receptor (ER), and/or positive progesterone receptor (PR), and positive Human endothelial growth Factor Receptor 2 (HER2). However, positive ER and negative PR are found more often. The prognosis of luminal B breast cancer is worse than Luminal A $(10,11)$. Basal-Like breast cancer is an aggressive subtype characterized by Triple Negative (negative ER, negative PR, and negative HER2), cytokeratin 5/6, and/or positive EGFR (12). Positive HER2 type (HER2 +) is a subtype that is rarely found in breast cancer patients but is an aggressive subtype and is often found at advanced stage breast cancer. Estrogen and progesterone receptors in this subtype are negative $(10,11)$.

\section{Overview of Piper retrofractum Vahl Fruit}

Piper retrofractum Vahl has many local names like cabai jawa (Java), cabi sola (Madura), cabia (Sulawesi), lada panjang (Malay) and tabia bun (Bali). In addition to its abundant presence in Bali, Balinese long pepper (tabia bun) is also widely grown throughout Indonesia because it is highly adaptable. Some bioactive compounds such as piperine alkaloid, cavisin, piperidine, isobutane-trans-2-trans4-dienamide; saponins, polyphenols, essential oils, palmitic acid, tetrahydropyperic acid, 1 undesilenyl-3,4 methylenedioxybenzene, sesamin, and piplartine are present in Balinese long pepper fruit. The percentage of piperine content in this fruit is about $2 \%$ and essential oil is about $1 \%$. Balinese long pepper fruit's essential oils consists of three main components, namely $\beta$-caryophyllene $(17 \%)$, pentadecane $(17.8 \%)$ and $\beta$-bisabolene $(11.2 \%)(13,14)$. 
Anti-Proliferative and Anti-Metastatic Agents of Piper retrofractum Vahl in Breast Cancer

(A)

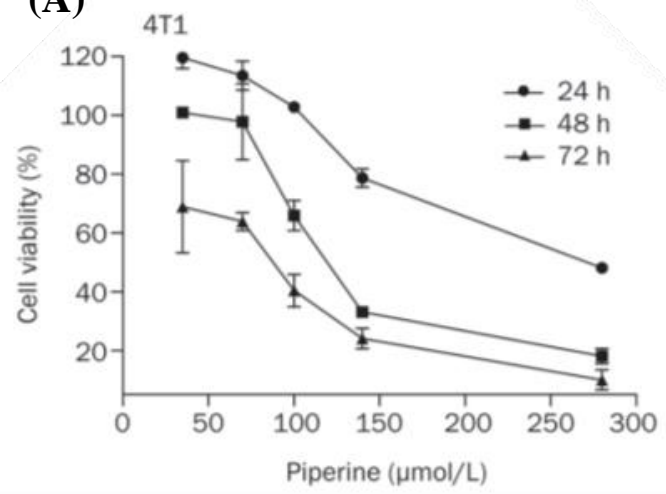

(B)

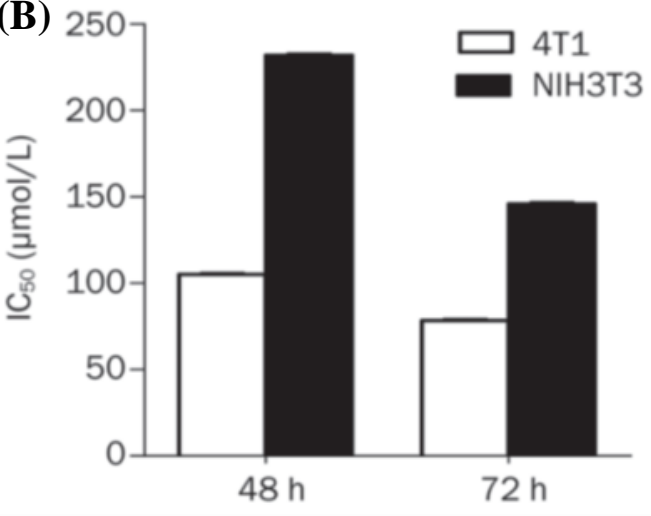

Figure 1. (A) Inhibition of growth by piperine in 4T1 cells; (B) The IC50 values of piperine on 4T1 cells (15).
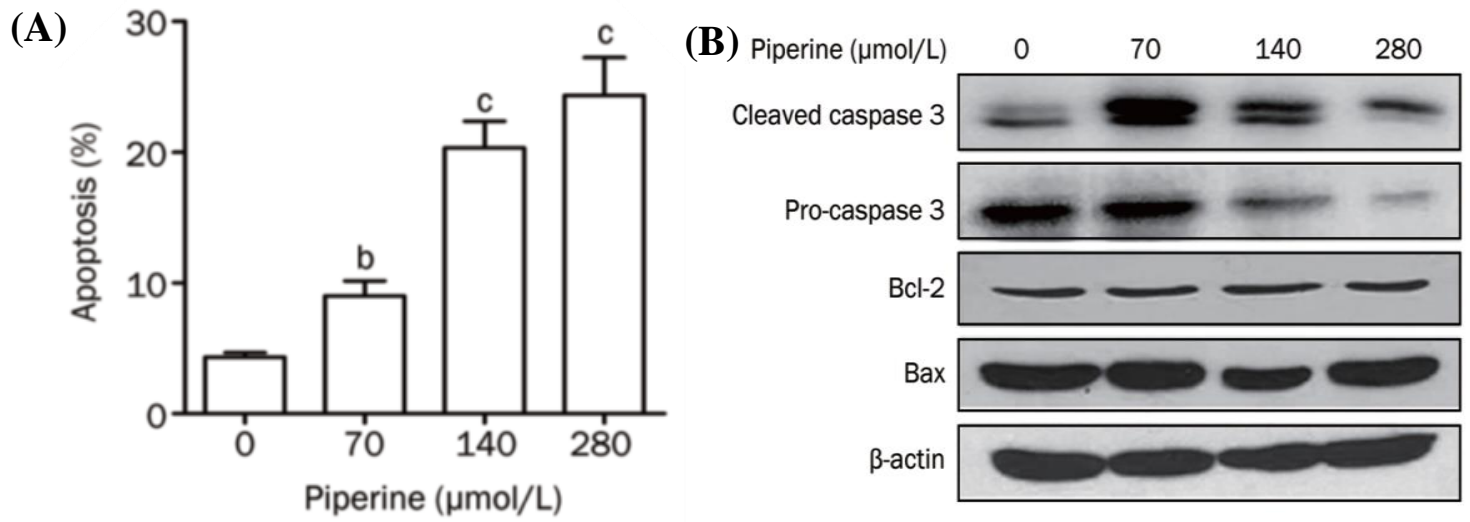

Figure 2. (A) The apoptotic cell death was quantified as Annexin V; (B) Western blot analysis of caspase 3, Bcl-2 and Bax in 4T1 cells treated with or without piperine (15).
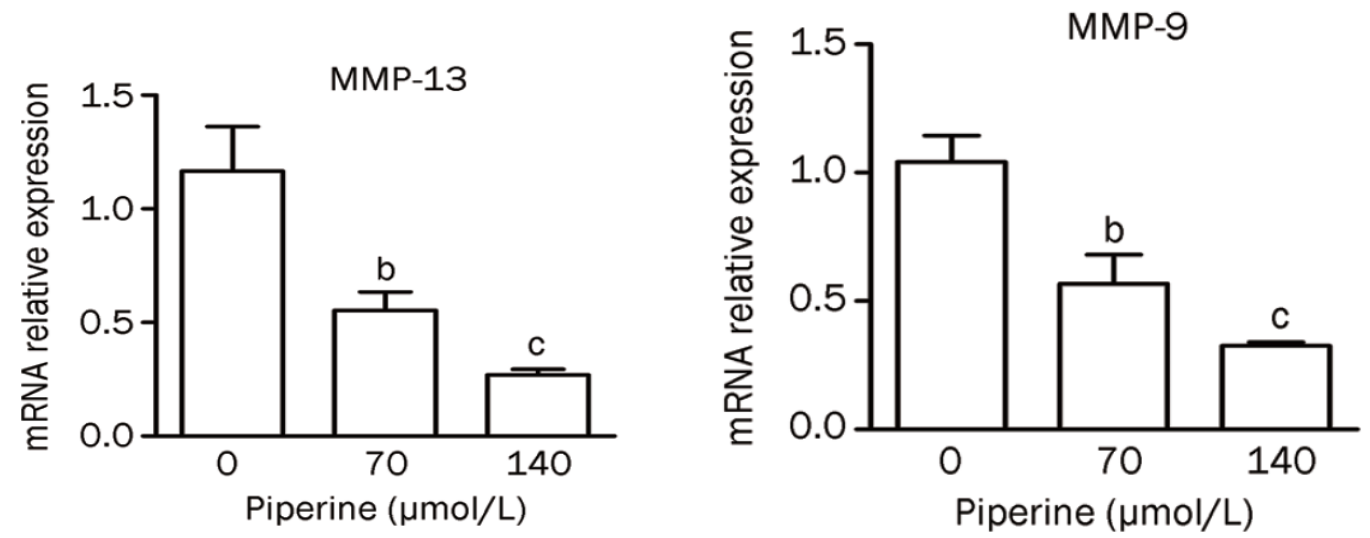

Figure 3. Down-regulated the expression of MMP-9 and MMP-13. The mRNA expression of MMP-9 and 13 in $4 \mathrm{~T} 1$ cells treated by piperine at different concentrations $(0,70$, and $140 \mu \mathrm{mol} / \mathrm{L})$ for $24 \mathrm{~h}$ was detected by real-time PCR and normalized to the expression of GAPDH in each sample (15). 


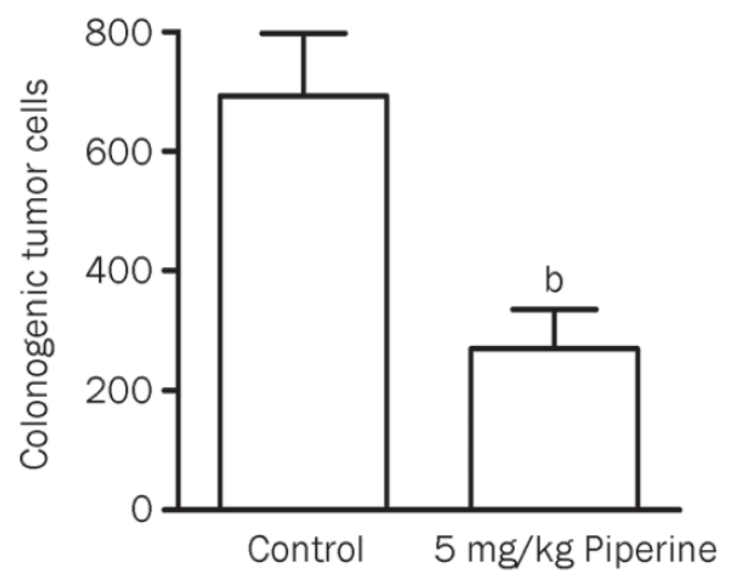

Figure 4. Piperine inhibited the metastasis of $4 \mathrm{~T} 1$ tumors in vivo. $4 \mathrm{~T} 1$ cells were implanted subcutaneously into the female BALB/c mice. After three days of implantation, piperine ( 0 and $5 \mathrm{mg} / \mathrm{kg}$ ) was dissolved in $0.2 \%$ DMSO and intratumorally injected every three days for three times(15).
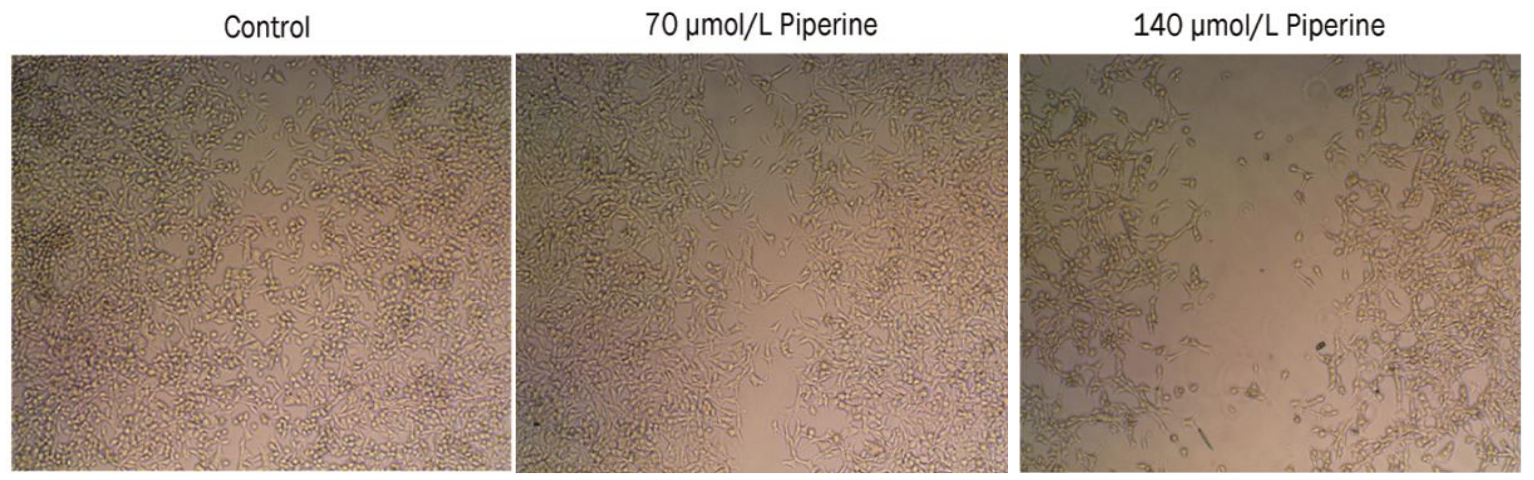

Figure 5. Piperine inhibited 4T1 cell migration in vitro (15).

\section{Discusion}

Until now, piperine is the first and the most effective bio enhancer. Piperine can enhance the bioavailability of many drugs by increasing absorption from intestine, suppressing drugs metabolism in lung and liver tissue by inhibiting CYP3A4 and P84 glycoprotein P84(16). According to pharmacokinetic study in humans, there is no accumulation of piperine after daily oral dose of $20 \mathrm{mg}$ piperine for 7 days which is observed in blood serum. About $97 \%$ of piperine will be absorbed in the intestine while the remaining $3 \%$ will be excreted in urine and feces (17). There are no studies showing piperine toxicity in humans in the included literature, but in vivo studies show that doses above $1.12 \mathrm{mg} / \mathrm{kg}$ is able to cause central nervous system depression and reproductive toxicity. The in vitro anti-proliferative effect of piperine was tested on 4T1 cells at dose of $140 \mu \mathrm{mol} / \mathrm{L}$ and $280 \mu \mathrm{mol} / \mathrm{L}$ for 24 hours (Figure 1A). The results showed reduction in cell viability from $100 \%$ to $78 \%$ and $48 \%$ compared to the control group. Piperine administration for 48 hours at dose of $140 \mu \mathrm{mol} / \mathrm{L}$ and $280 \mu \mathrm{mol} / \mathrm{L}$, was able to cause decreased in cell viability from $100 \%$ to $33 \%$ and $18 \%$ (Figure 1A). IC50 values for piperine were $105 \pm 1.08 \mu \mathrm{mol} / \mathrm{L}$ for 48 hours, and $78.52 \pm 1.06 \mu \mathrm{mol} / \mathrm{L}$ for 72 hours treatment (Figure 1B), which indicated that inhibition of breast cancer cell growth was dose dependent (18).

The piperine content in $100 \mathrm{ug} / \mathrm{mL}$ Piper retrofractum Vahl extract successfully acts as an antiproliferative as much as $40 \%$ in breast cancer cells. ${ }^{[18]}$ Besides piperine, Piper retrofractum Vahl extract also contains $6.56 \mathrm{mg} \mathrm{QE} \mathrm{/} \mathrm{g} \mathrm{flavonoid} \mathrm{compounds} \mathrm{which} \mathrm{can} \mathrm{increase} \mathrm{p53} \mathrm{expression} \mathrm{and} \mathrm{have} \mathrm{95.89 \%}$ inhibitory effect in MCF-7 cells with $250 \mu \mathrm{g} / \mathrm{mL}$ concentration (19). The anti-metastatic effect of piperine can be tested using different concentrations, starting from 0, 140, and $280 \mu \mathrm{mol} / \mathrm{L}$ for 24 hours, analysed by Annexin V-FITC / PI double-labelled flow cytometry. Administration of piperine of 140 and $280 \mu \mathrm{mol} / \mathrm{L}$ for 24 hours, increased apoptosis by $24.2 \%$ and $23.6 \%$ compared to control group (Figure 2A). Studies by 
Lai et al. show that, the effect of piperine on the expression levels of the Bcl-2 family, the pro-apoptotic Bax and the anti-apoptotic Bcl-2, which regulates mitochondrial apoptosis (Figure 2B). When Bax is overexpressed in cells, apoptotic death in response to death signals is accelerated, while Bcl-2 is overexpressed, it is heterodimerized with Bax and the cell death is repressed. Following the exposure to piperine, it is found that there is no change of Bax and Bcl-2 at protein levels in the $4 \mathrm{~T} 1$ cells, indicating that the apoptosis induced by piperine is not dependent of the Bcl-2 pathway. In addition, the anti-metastatic effect of piperine is also related to Matrix Metalloproteinases (MMPs). This protein has the capacity to reduce the extracellular matrix (ECM) component and change its biological function. It is well-known that the process of tumor cell metastasis requires the degradation of ECM molecules in the basement membrane, which is the largest barrier between cancer cells and bloodstream. The essential proteases that are involved in ECM degradation contain MMPs (15).

The content of piperine in Piper retrofractum Vahl can affect the expression of matrix metalloproteinases (MMPs) such as MMP-1, MMP-2, MMP-3 and MMP-9, MMP-13 (20). MMP-9 is one of the largest MMP types in all MMP family of proteinase enzymes which has $92 \mathrm{kDa}$ molecular weight. MMP-9 has the ability to increase type IV collagen degradation, which is the main component of the basal membrane which is also involved in cancer cells metastasic process. Research in 2014 shows that increase in MMP-9 expression is directly proportional to the increase in tumor histology grade and metastasis (21). Piperine can significantly reduce MMP-9 and MMP-13 expressions (Figure 3). It has been reported that piperine can suppress MMP-9 expression in tumor cells through inhibition of PKC $\alpha$ and ERK phosphorylation and reduction of NF-KB and AP-111 activation. MMP-13 has been shown to be expressed in more invasive breast carcinoma cells, and some evidence indicates that increased expression of MMP-13 derived independently from tumors has poor prognosis. It is thought that the inhibitory effect of piperine on oxygenase, p450 isoenzymes and cycloxygenase- 1 expression can contribute to antimetastatic quality (15).

4T1 cells can also metastasize to various organs, such as the lungs. Lai et al. showed that less metastasis in the lungs of mice that had been given piperine $5 \mathrm{mg} / \mathrm{kg}$ compared with control mice (Figure 4). The results indicated that piperine not only suppressed the growth of local primary tumors but also effectively controlled the occurrence of spontaneous metastasis. Besides, piperine is also be able to inhibit the ability of in vitro 4T1 cells migrations which can be proven by wound healing tests. Piperine was administered to cell at concentrations of 0,70 , and $140 \mu \mathrm{mol} / \mathrm{L}$, and the results showed that piperine inhibited 4T1 cell migration in dose-dependent manner (Figure 5) (15). Piperine is a compound that can inhibit epidermal growth factor (EGF) by inducing reduction on MMP expression and working through inhibition of NF- $\mathrm{KB}$ and activation of AP-1 by interfering extracellular signal-regulated kinase (ERK) signaling pathway 1/2, p38 MAPK, and Akt which results in inhibition of cell migration (20).

\section{Conclusion and suggestion}

Balinese long pepper (Piper retrofractum Vahl) contains piperine, flavonoids and essential oils which have many properties such as, antioxidants, antimalarial, antibacterial, central nervous depressant activity, antidiabetic and even anticancer. Piperine can increase the bioavailability of many drugs by increasing absorption from the intestine, suppressing the metabolism of drugs in lung and liver tissue by inhibiting CYP3A4 and P84 glycoprotein P84. Piperine acts as bioenhancer that is widely used today since it is easily absorbed in the intestine, and can be excreted through urine and feces, and causing minimal toxic effects. Piperine is able to reduce $40 \%$ of breast cancer cell proliferation. Flavonoid content in Piper retrofractum Vahl can also increase the expression of p53 and has inhibitory effect towards MCF-7 breast cancer cells growth. Piperine can inhibit epidermal growth factor (EGF) by inducing reduction in MMP-9 and MMP-13 expression. Piperine will work through inhibition of NF- $\mathrm{KB}$ and PKC $\alpha$ phosphorylation and AP-1 activation by interfering extracellular signal-regulated kinase (ERK) signalling pathway 1/2, p38 MAPK, and Akt thus, it has the ability to inhibit breast cancer cells migration and metastasis. Further research is needed to determine the effectiveness of piperin in Piper retrofractum at the in vivo level research and clinical trials. It is hoped that the piperin extract in the Piper retrofractum can be used as a therapy for the treatment of breast cancer in the future.

\section{Reference}

1. Bray F, J, Soerjomataram I, R.L S, L.A T, Jernal A. Global Cancer Statistics 2018: GLOBOCAN Estimates of Incidence and Mortality Worldwide for 36 Cancers in 185 Countries. Ca Cancer J Clin. 2018;68:394-424.

2. International Agency for Research on Cancer. Breast cancer awareness month 2018 [Internet]. 2018 [cited 2019 Sep 30]. Available from: https://www.iarc.fr/news-events/breast-cancer-awarenessmonth-2018/ 
3. Kementrian Kesehatan Republik Indonesia. Hari Kanker Sedunia [Internet]. 2019 [cited 2019 Sep 30]. Available from: http://www.depkes.go.id/pdf.php?id=19020100003

4. Dinas Kesehatan Provinsi Bali. Profil Kesehatan Provinsi Bali Tahun 2015 [Internet]. 2015 [cited 2019 Sep 30]. Available from: http://www.diskes.baliprov.go.id/files/subdomain/diskes/Profil Kesehatan Provinsi Bali/Tahun 2015/Bali_Profil_2015.pdf

5. Kesehatan M. Penanggulangan Kanker Payudara dan Kanker Leher Rahim. INDONESIA KKR, editor. Jakarta; 2015.

6. Gradishar W, B.O A, R B, S.L B, H.J B, A C. Breast Cancer, Version 4.2017, NCCN Clinical Practice Guidelines in Oncology. J Natl Compr Canc Netw. 2018;16(3).

7. Vaghora B, Shukla V. Impact of Different Phytochemical Classes and Ayurvedic Plants in Battle against Cancer. Int J Phar Sci Res (IJPSR. 2016;7(10).

8. A.M K, F.H B. Breast Cancer: Insights into Risk Factors, Pathogenesis. Diagnosis and Management J Can Res Treat. 2015;3(2).

9. Daeman A, G M. HER2 is not a cancer subtype but rather a pan-cancer event and is highly enriched in AR-driven breast tumors. Breast Cancer Res. 2018;20(8).

10. Dai X, Li T, Bai Z, Yang Y, Liu X, J Z, et al. Breast cancer intrinsic subtype classification, clinical use and future trends. Am J Cancer Res. 2015;5(10).

11. Cho N. Molecular subtypes and imaging phenotypes of breast cancer. Ultrasonography. 2016;35(4).

12. Kim Y, Choi J, Lee J, Kim YS. Expression of lactate/H+ symporters MCT1 and MCT4 and their chaperone CD147 predicts tumor progression in clear cell renal cell carcinoma: immunohistochemical and The Cancer Genome Atlas data analyses. Human Pathology. 2015;46:104-112.

13. Evizal R. Status Fitofarmaka Dan Perkembangan Agroteknologi Cabe Jawa (Piper Retrofractum Vahl. J Agrotropika. 2013;18(1).

14. Chopra B, A.K D, A.P K, D.N P. Piperinee and its various physicochemical and biological aspects: A Review. Open Chemistry Journal. 2016;3:75-96.

15. Lai L, Fu Q, Liu Y, Jiang K, Guo Q, Chen Q. Piperine suppresses tumor growth and metastasis in vitro and in vivo in a 4T1 murine breast cancer model. Acta Pharmacol Sin. 2012;33(4).

16. Pachauri M, E D, P.C G. Piperine loaded PEG-PLGA Nanoparticles: preparation, characterization and targeted delivery for adjuvant breast cancer chemotherapy. Journal of Drug Delivery Science and Technology. 2015;1-51.

17. Rohloff J. Risk Assessment of other substance-Piperine. Opinion of the Panel on Food Additives, Flavourings, Processing Aids. In: Materials in Contact with Food and Cosmetics of the Norwegian Scientific Committee for Food Safety. 2016. p. 1-43.

18. Ekowati HENY. Zingiber Officinale, Piper Retrofractum and Combination Induced Apoptosis and p53 Expression in Myeloma and WiDr Cell Lines. HAYATI Journal of Biosciences. 19(3).

19. Mulia K. Aktivitas Antikanker dan Antioksidan Ekstrak Cabe Jawa Secara In Vitro Terhadap Sel MCF7 yang Berasal dari Berbagai Lokasi di Indonesia (Thesis. Bogor: Institut Pertanian Bogor; 2015.

20. A.R R, M B. Cancer Chemoprevention and Piperine: Molecular Mechanisms and Therapeutic Opportunities. Front Cell Dev Biol. 2018;6:1-12.

21. Toth M, Sohail A, Fridman R. Assesment of gelatines (MMP-2 and MMP-9) by gelatin zygmography. Methods Mol Biol. 2012;878:121-35. 